\title{
Muslim Consumers' Preferences on Interest in Buying Halal Food and Beverage Products with moderating variables of gender and education in DKI Jakarta
}

\author{
Firdayetti ${ }^{1}$, Yuswar Zainul Basri ${ }^{2}$, Willy Arafah $^{3}$ \\ ${ }_{1,2,3}$ EF Trisakti University \\ 1,2,3 Jl. Kyai Tapa No.1,Tomang, Kec. Grogol petamburan, Kota Jakarta Barat, Daerah Khusus \\ lbukota Jakarta 11440 \\ e-mail: $\underline{\text { firdayetti@trisakti.ac.id }}{ }^{1}$, yuswarzainulbasri@gmail.com ${ }^{2}$, willy.arafah@gmail.com $^{3}$
}

Author Notification 8 January 2022 Final Revised 24 January 2022 Published 1 April 2023

To cite this document :

Firdayetti, Basri, Y.Z., \& Arafah, W. (2023). Muslim Consumers' Preferences on Interest in Buying Halal Food and Beverage Products with moderating variables of gender and education in DKI Jakarta. Aptisi Transactions on Management (ATM), 7(2), 113-124.

DOI :

https://doi.org/10.33050/atm.v7i2.1817

\begin{abstract}
The purpose of this study was to analyze the preferences of Muslim consumers towards buying interest in Halal Food and Beverage Products in DKI Jakarta. The independent variables are Price, Islamic Brand, Product Knowledge and Religious Knowledge with the dependent variable being Product Halal Intention with the variable gender and education moeration. Methodology used is quantitative with SEM AMOS analysis tool, the population is DKI Jakarta society, with 225 respondents aged 17 years and over who are Muslims as consumers of halal food and beverages as the sample. with the intent of the research. The results of the study directly have two variables that affect the halal intention of the product (product knowledge and religious knowledge on the halal intention of the product) and the second variable has no effect on the halal intention of the product (price and Islamic brand on the halal intention of the product). If using the moderating variables of gender and education, the four independent variables (price, Islamic brand, product knowledge and religious knowledge) have an effect on product halal intentions. The theoretical conclusion is that only 2 out of 4 variables congruent with the theory and the two are not congruent with the theory Administrative influences are applied based on consumer preferences as follows: Religious knowledge of prices, Islamic brands, product knowledge and halal products Intent when there are modulating variables.
\end{abstract}

Keywords: halal food and beverage, consumer preference, product halal intention 


\section{Introduction}

Indonesia is currently experiencing rapid macroeconomic growth with a rapidly growing middle class, as evidenced by the continued growth of GDP per capita.[1] Moreover, Indonesians, like the rest of the world, are increasingly experiencing an urbanization process. As a result, the Muslim population, which makes up nearly 90 li of Indonesia's total population, is also affected by these events. In large cities, this group of people increasingly leads a consumer lifestyle. This is especially true for a very large proportion of moderate Muslim groups. They are increasingly adopting a "modern" urban lifestyle supported by electronics and the latest fashion styles. Important indicators such as car sales, internet use and cell phone use have grown rapidly in recent years. It's not uncommon for middle-class and elite young people to vacation in highend shopping malls or big cities like Starbucks.[2]

Muslims in Indonesia make up $87.18 \%$ of the $2,325,000$ people. This is a massive halal market. According to the same report, Indonesia ranks in the top 10 in consumer ratings in all sub-sectors of the halal industry. Indonesia ranks first in Muslim spending on food, fifth in Muslim travel spending, third in Muslim spending on clothing and fifth in Muslim spending. In terms of media spending, it ranks sixth in drug distribution in Islamic countries.[3]

Food is an inevitable human need. Food is one of the basic requirements, so it must be readily available, safe, high-quality and nutritious, and it must be usable taking into account people's purchasing power and varying prices. Achieving all this would require the organization of a food system that protects both those who produce and consume food, as mentioned in many articles in the Quran and the hadith of the Prophet Muhammad (including those found in Sura). Almaida: "Eat the right and good food that Allah has given you, and fear Allah in whom you believe." Halal foods include meat and poultry, as well as other foods such as sweets, canned and frozen foods, dairy products, breads, organic foods, herbal products and other beverages. Halal means not only is it legal, but it is also good for your health. Halal food acquires the halal logo through the official halal certification process.[4] Receiving the Halal logo means Muslim consumers can consume with confidence in accordance with Sharia law. For non-Muslim consumers, the Halal logo represents a symbol of purity, quality, purity and safety.

Satisfaction of basic needs according to Islam is subdivided. First, if Haruri's need to be met and supported is not met, it threatens people's lives. The needs of Dharuri consist of complements: religious needs such as worship, food for intellectual needs such as alnafas/study for self, spiritual needs such as alakla, and family needs such as marriage. Alnaphs meet and Alnaphs meet needs. Wealth: Second, the need for Hajjiyah, ie. Secondary Necessity: Third, the need for tachsinia is a tertiary or additional need.[5] According to research, Makashid Sharia contains the great philosophy of protecting human dignity and being the cornerstone of Islamic consumption and the concept of Halal Toyban, which emphasizes the interests of umma. Methods used are literature reviews and studies of web sources.

The state must ensure that all residents practice their religion and beliefs, including meeting the need for halal food according to the religion of all Muslims. This is related to Article 4 of the Consumer Protection Act, 1999 Decree No. Applies to 1999. Consistent with the consumer rights set out in Section 8, this includes, inter alia, the right to consume goods and/or services for the convenience of consumption. Food according to your beliefs. According to UUPK, all manufacturers must transparently list the ingredients in every food they produce to protect the interests of consumers. Especially in today's environment, it is very difficult to distinguish between halal and haram food over time. In-depth knowledge of food science and technology and knowledge of Islamic law are required.[6]

Manufacturing activity is the link between consumption and distribution. Manufacturing activities that produce products and services and then consume them, consumers and manufacturers who produce them, and providers of products and services understand that this is an opportunity for businesses to meet the needs of life by focusing on the composition of products and services. Produce.[7] 
According to Suratmono, deputy director of food and hazardous substances at the FDA, a 2012 study found that only $29 \%$ of Indonesian consumers pay attention to halal labeling. $59 \%$ prefer taste and nutrition, while the rest pay attention to the brand.[8]

Brands are said to have a positive effect on consumer interest in a product. As a result of the Sobel test, the brand loyalty variable was found to be significant as an intermediate variable. [9]... Halal brand and purchase intention showed a negative correlation with a correlation coefficient of 0.55 . These results suggest that customers who want to purchase halal cosmetics will prefer halal cosmetics to brands.[10]

According to the Global Islamic Economy Report, the global potential of the halal lifestyle industry is expected to grow from $\$ 2$ billion in 2016 to $\$ 3.1$ billion in 2022.[11] This is an opportunity for Indonesia, which ranked 11th in 2017-2018. Halal industry. Anwar Bashori, head of economics and sharia finance at Bank Indonesia, said the two companies could make Indonesia's name known to the global halal industry. Food and fashion, especially clothing, are people's daily needs.[12] "We are developing both sectors, and we do not need to import them," Anwar said at a meeting in Jakarta's Business Intelligence Building.

The potential of the domestic market for halal products is immeasurable. In addition, today's Shariah-based industries, including halal products, are developing rapidly in the face of growing religious trends among Indonesian people. As a result, the demand for halal products in the domestic market will increase in the future.[13]

Which halal product you buy depends on many factors. This is the behavior of Islamic consumers towards their interest in buying halal products. Consumption of halal products is a sacred commandment for Muslims, but certain internal and external factors can influence interest in purchasing halal products. Therefore, it is necessary to fully understand the willingness to purchase halal and its determinants so that consumers' behavior can be appropriately managed and controlled to improve halal performance.[14]

\section{Research Method}

This study consists of variables of buying interest or halal product intention, price, Islamic brand, product knowledge, religious knowledge with several hypotheses. This research is research that tests hypotheses that are supported by existing theories. The results of the later research may be following the theory or previous research or may not be following the theory and the results of previous research.[15]

The independent variable is a variable that affects other variables. In this case, the independent variable from Purchase Interest or Halal Product Intention is Price, Islamic Brand, Product Knowledge, Religious Knowledge. This is also called the antecedent. The dependent variable is the variable that is influenced by the independent variable.[16] In this case, the purchase intention (halal product intention) is called the Consequence. Consequences are variables that have an impact or arise because of the existence of another variable. 
In this study, the variable used as the dependent variable is buying interest or halal product intention. (PHI), is a process where consumers analyze their knowledge of the product, compare the product with other similar products, and decide on which product to buy.[17]

\begin{tabular}{l|l|l}
\hline \multicolumn{1}{c|}{ Variable } & \multicolumn{1}{c|}{ Indicator } & \multicolumn{1}{c}{ Source } \\
\hline $\begin{array}{l}\text { Buying Interest or Halal } \\
\text { Product Intention }\end{array}$ & $\begin{array}{l}\text { 1. } \begin{array}{l}\text { Always want to buy halal } \\
\text { products }\end{array} \\
\text { 2. } \begin{array}{l}\text { Continuing to consume } \\
\text { halal products }\end{array}\end{array}$ & $\begin{array}{l}\text { Lada, tanakinjal, and Amin } \\
\mathbf{( 2 0 0 9 )}\end{array}$ \\
& $\begin{array}{l}\text { 3. Willing to wait for halal } \\
\text { products }\end{array}$ & \\
& $\begin{array}{l}\text { W. Willing to pay extra } \\
\text { Intention to recommend } \\
\text { halal products }\end{array}$ & \\
\hline
\end{tabular}

Table 1. Indikator Halal Product intention

Price is the amount of money that must be paid to purchase a product or service.[18] To a broader extent, the price is a certain amount exchanged by consumers to get the benefits of ownership in using the product or service. The price factor is a consumer's subjective consideration of high or low prices for food and beverages. According to (Uci Yuliati 2011), the price is a factor that is considered in deciding the purchase of food.[19]

\begin{tabular}{|c|c|c|}
\hline Variable & Indicator & Source \\
\hline Price & $\begin{array}{l}\text { 1. Affordable prices } \\
\text { 2. Price according to taste } \\
\text { 3. Prices according to } \\
\text { shape and size } \\
\text { 4. Price according to } \\
\text { packaging } \\
\text { 5. Discounts or discounts } \\
\text { affect purchases }\end{array}$ & Uci Yuliati, 2011 \\
\hline
\end{tabular}

Table 2. Indikator Price

\begin{tabular}{|c|c|c|}
\hline Variable & Indicator & Source \\
\hline Islamic Brand & $\begin{array}{l}\text { 1. } \begin{array}{l}\text { Brand is an important } \\
\text { factor }\end{array} \\
\text { 2. Buying halal food } \\
\text { products is basically a } \\
\text { brand } \\
\text { 3. Islamic Brands influence } \\
\text { trust in the purchase and } \\
\text { consumption of halal } \\
\text { food and beverage } \\
\text { products } \\
\text { 4. Islamic Brand is enough } \\
\text { to be a halal indication of } \\
\text { halal food and beverage } \\
\text { products } \\
\text { 5. Keep buying halal food } \\
\text { and beverage products } \\
\text { even though they are } \\
\text { not the desired brand } \\
\text { (product) }\end{array}$ & $\begin{array}{l}\text { Golnaz, Zainal,dan Mad } \\
\text { Nazir. } 2012 \text { dan Wilson and } \\
\text { liu } 2011\end{array}$ \\
\hline
\end{tabular}




\begin{tabular}{l|l|l}
\hline & & \\
\hline
\end{tabular}

\section{Table 3. Indikator Islamic Brand}

Methods and Measurement of Research Variables. This study uses a questionnaire. The variable measurement used is the Likert scale, which measures the attitude of respondents towards subjects and objects or on specific events (Sekaran and Bougie 2016). Based on the results of data collection, the authors make a profile of the respondents to make it easier to know the condition of the respondents. Some of the characteristics of the respondent's profile are shown in table 4.[20] are as follows:

\begin{tabular}{|c|c|l|}
\hline No & \multicolumn{1}{|c|}{ Description } & \multicolumn{1}{c|}{ Total } \\
\hline $\mathbf{1 .}$ & Gender & Female \\
\hline & & Male \\
\hline $\mathbf{2 .}$ & Age & $17-23$ years \\
\hline & & 24 years -30 years \\
\hline & & 31 years - 40 years \\
\hline & & 41 years - 50 years \\
\hline & & $>51$ years \\
\hline $\mathbf{3 .}$ & Education & SMA or Mahasiswa \\
\hline & & Diploma 1 s/d Sarjana 1 \\
\hline & & Postgraduate \\
\hline $\mathbf{4 .}$ & Status & Not Married yet \\
\hline & & Married \\
\hline & & Not Married yet \\
\hline $\mathbf{5 .}$ & Profession & Private Civil Servant \\
\hline & & Private employees \\
\hline & & entrepreneur \\
\hline & & Part Time \\
\hline
\end{tabular}

Tabel 4. Respondent Profile

\subsection{Conceptual Framework}

Based on the background, objectives, and analysis of literature studies and literature studies, the conceptual framework of this research is the participation of Muslim consumers, both women, and men, which are influenced by price, Islamic brand, product knowledge, and religious knowledge. The conceptual framework is based on theories and previous research, which will become the research model.

This research will be conducted with an equation model structure, and the data used are primary data, namely to determine the effect of price, Islamic brand, product knowledge, religious knowledge mediated by gender, and type of work on halal product intention. 
Figure 1. Conceptual Framework

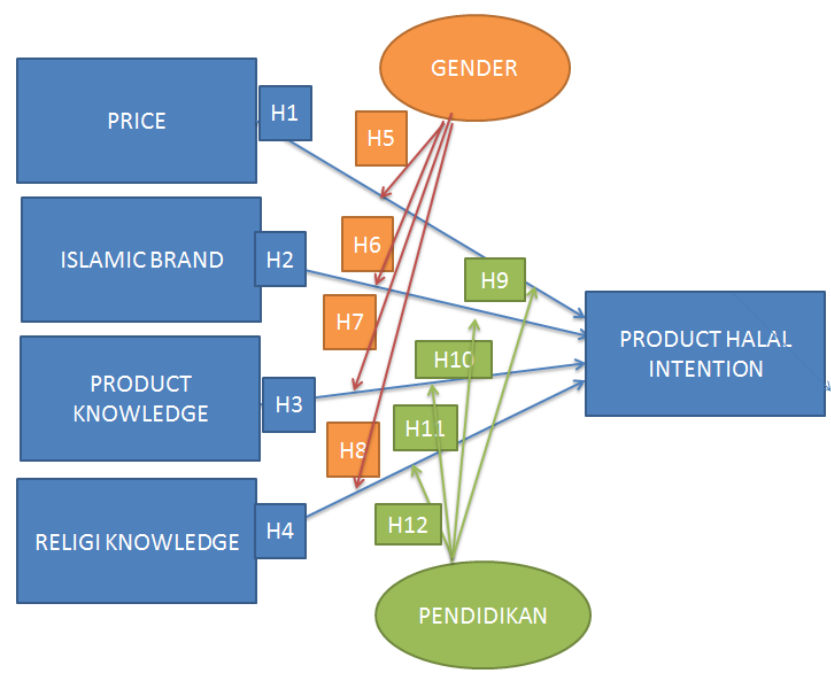

\subsection{Literature Review}

Al-Quran and Sunnah are absolute sources of knowledge, interpreted through the evolution of human thought, which will be implemented later. The implementation process is through the Interaction Integration and Evolution (IIE) process. The symbol ${ }^{*}$ is a symbol of science from the ljma' ulama, which in the following process science and humans meet through a process of deliberation (strategic process). It is denoted by $X(\theta)$.

Good consumers can determine the food and drinks be consumed, whether the products purchased follow the rules set by Allah so that a healthy and beneficial life is achieved for the people around them and the whole community.

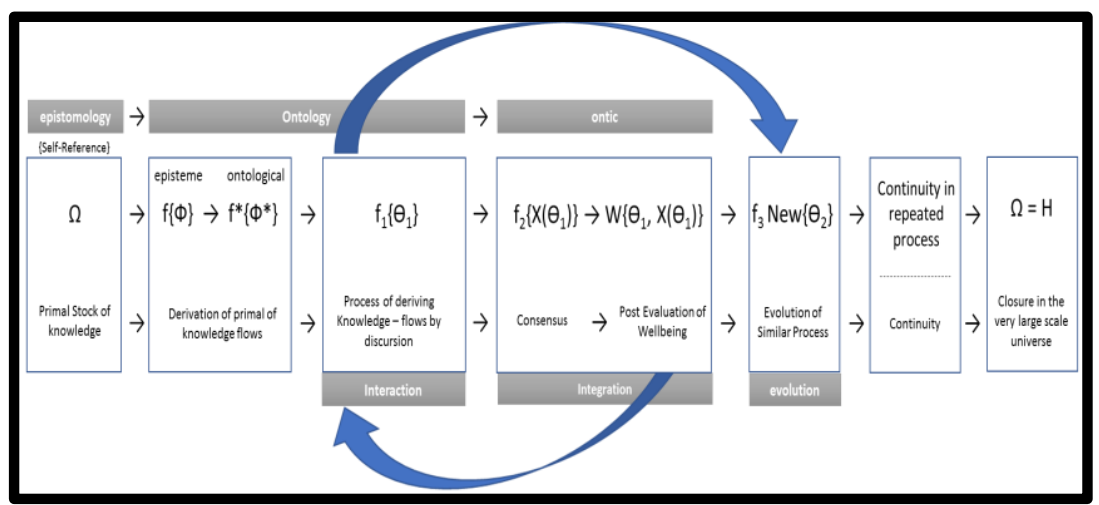

Figure 2 : Konsep Tawhidi String Relation (TSR)

Rumus TSR:
$[(\Omega, S) \rightarrow \rightarrow \quad \rightarrow \quad * \quad \rightarrow$
$\Omega=$ Al-Qur'an
$\left.X^{2}, X^{3}, X^{4}, Y\right)=\theta N$
$\mathrm{S}=$ Sunnah
$\mathrm{X}_{1}=$ variabel price
$\theta^{*}=$ ljma'
$\mathrm{X}_{2}=$ Variabel Islamic brand
$\theta=$ Teori
$\mathrm{X}_{3}=$ Variable product knowledge
$X(\theta)=$ Suratic Process
$\mathrm{X}_{4}=$ Variable religi knowledge
$\mathrm{Y}=$ Variable halal product intention 
$\mathrm{W}=$ Wellbeing (Maslahat) $\quad \theta \mathrm{N}=$ New found theory

\subsection{Hypotheses}

The SEM analysis tool used to process the data performed in this study includes several independent variables: price, Islamic brand, product knowledge, religious knowledge, and dependent variables, namely, the intention of halal products by gender, two median variables. Moreover, education Based on this, there are 12 hypotheses.

\begin{tabular}{|c|c|c|c|c|}
\hline & Hipotesis & $\begin{array}{l}\text { Estimat } \\
\text { e }\end{array}$ & $\begin{array}{l}\text { P- } \\
\text { Value }\end{array}$ & Keputusan \\
\hline Hipotesis 1 & $\begin{array}{l}\mathrm{H}_{1}: \text { Price berpengaruh terhadap } \\
\text { Product Halal Intention }\end{array}$ & 0,036 & 0,415 & $\begin{array}{l}\text { Ha } 1 \text { tidak } \\
\text { didukung }\end{array}$ \\
\hline Hipotesis 2 & $\begin{array}{l}\mathrm{H}_{2} \text { : Islamic Brand berpengaruh } \\
\text { terhadap Product Halal Intention }\end{array}$ & 0,046 & 0,349 & $\begin{array}{l}\text { Ha2 tidak } \\
\text { didukung }\end{array}$ \\
\hline Hipotesis 3 & $\begin{array}{l}\mathrm{H}_{3}: \text { Product Knowledge } \\
\text { berpengaruh terhadap Product } \\
\text { Halal Intention }\end{array}$ & 0,493 & 0,000 & $\begin{array}{l}\mathrm{Ha} 3 \\
\text { didukung }\end{array}$ \\
\hline Hipotesis 4 & $\begin{array}{l}\mathrm{H}_{4} \text { : Religi Knowledge berpengaruh } \\
\text { terhadap Product Halal Intention }\end{array}$ & 0,258 & 0,025 & $\begin{array}{l}\mathrm{Ha}_{4} \\
\text { didukung }\end{array}$ \\
\hline \multirow[t]{3}{*}{ Hipotesis 5} & $\begin{array}{l}\text { H5 kelompok Perempuan: } \\
\text { Price } \square \text { Product Halal Intention }\end{array}$ & 0,104 & 0,052 & \multirow[t]{3}{*}{$\begin{array}{l}\text { Ha5 } \\
\text { didukung }\end{array}$} \\
\hline & $\begin{array}{l}\text { H5 kelompok Laki - Laki: } \\
\text { Price } \square \text { Product Halal Intention }\end{array}$ & 0,153 & 0,038 & \\
\hline & \multicolumn{3}{|c|}{ Nilai Probability Level: 0,000} & \\
\hline \multirow[t]{3}{*}{ Hipotesis 6} & $\begin{array}{l}\text { H6 kelompok Perempuan: } \\
\text { Islamic Brand } \square \text { Product Halal } \\
\text { Intention }\end{array}$ & 0,156 & 0,006 & \multirow[t]{2}{*}{$\begin{array}{l}\text { Ha6 } \\
\text { didukung }\end{array}$} \\
\hline & $\begin{array}{l}\text { H6 kelompok Laki - Laki: } \\
\text { Islamic Brand } \square \text { Product Halal } \\
\text { Intention }\end{array}$ & 0,206 & 0,004 & \\
\hline & \multicolumn{4}{|c|}{ Nilai Probability Level: 0,000} \\
\hline \multirow[t]{3}{*}{ Hipotesis 7} & $\begin{array}{l}\text { H7 kelompok Perempuan: } \\
\text { Product Knowledge } \square \text { Product } \\
\text { Halal Intention }\end{array}$ & 0,670 & 0,000 & \multirow[t]{2}{*}{$\begin{array}{l}\mathrm{Ha}_{7} \\
\text { didukung }\end{array}$} \\
\hline & $\begin{array}{l}\text { H7 kelompok Laki - Laki: } \\
\text { Product Knowledge } \square \text { Product } \\
\text { Halal Intention }\end{array}$ & 0,539 & 0,000 & \\
\hline & \multicolumn{4}{|c|}{ Nilai Probability Level: $\mathbf{0 , 0 0 0}$} \\
\hline \multirow[t]{3}{*}{ Hipotesis 8} & $\begin{array}{l}\text { H8 kelompok Perempuan: } \\
\text { Religi Knowledge } \square \text { Product Halal } \\
\text { Intention }\end{array}$ & 0,427 & 0,006 & \multirow[t]{2}{*}{$\begin{array}{l}\text { Has } \\
\text { didukung }\end{array}$} \\
\hline & $\begin{array}{l}\text { H8 kelompok Laki - Laki: } \\
\text { Religi Knowledge } \square \text { Product Halal } \\
\text { Intention }\end{array}$ & 0,572 & 0,000 & \\
\hline & \multicolumn{4}{|c|}{ Nilai Probability Level: 0,000 } \\
\hline \multirow[t]{4}{*}{ Hipotesis 9} & $\begin{array}{l}\mathrm{H}_{9} \text { kelompok Pendidikan Rendah: } \\
\text { Price } \square \text { Product Halal Intention }\end{array}$ & 0,050 & 0,491 & \multirow[t]{3}{*}{$\begin{array}{l}\text { Ha9 } \\
\text { didukung }\end{array}$} \\
\hline & $\begin{array}{l}\text { H9 kelompok Pendidikan Sedang: } \\
\text { Price } \square \text { Product Halal Intention }\end{array}$ & 0,185 & 0,022 & \\
\hline & $\begin{array}{l}\text { H9kelompok Pendidikan Tinggi: } \\
\text { Price } \square \text { Product Halal Intention }\end{array}$ & 0,122 & 0,059 & \\
\hline & \multicolumn{4}{|c|}{$\begin{array}{ll}\text { Nilai Probability Level: } \mathbf{0 , 0 0 0}\end{array}$} \\
\hline Hipotesis 10 & $\begin{array}{l}\text { H} 10 \text { kelompok Pendidikan Rendah: } \\
\text { Islamic Brand } \square \text { Product Halal } \\
\text { Intention }\end{array}$ & 0,171 & 0,039 & $\begin{array}{l}\text { Ha } 10 \\
\text { didukung }\end{array}$ \\
\hline
\end{tabular}

Muslim Consumers' Preferences on Interest in Buying Halal Food and Beverage Products with moderating variables of gender and education in DKI Jakarta (Firdayetti) 


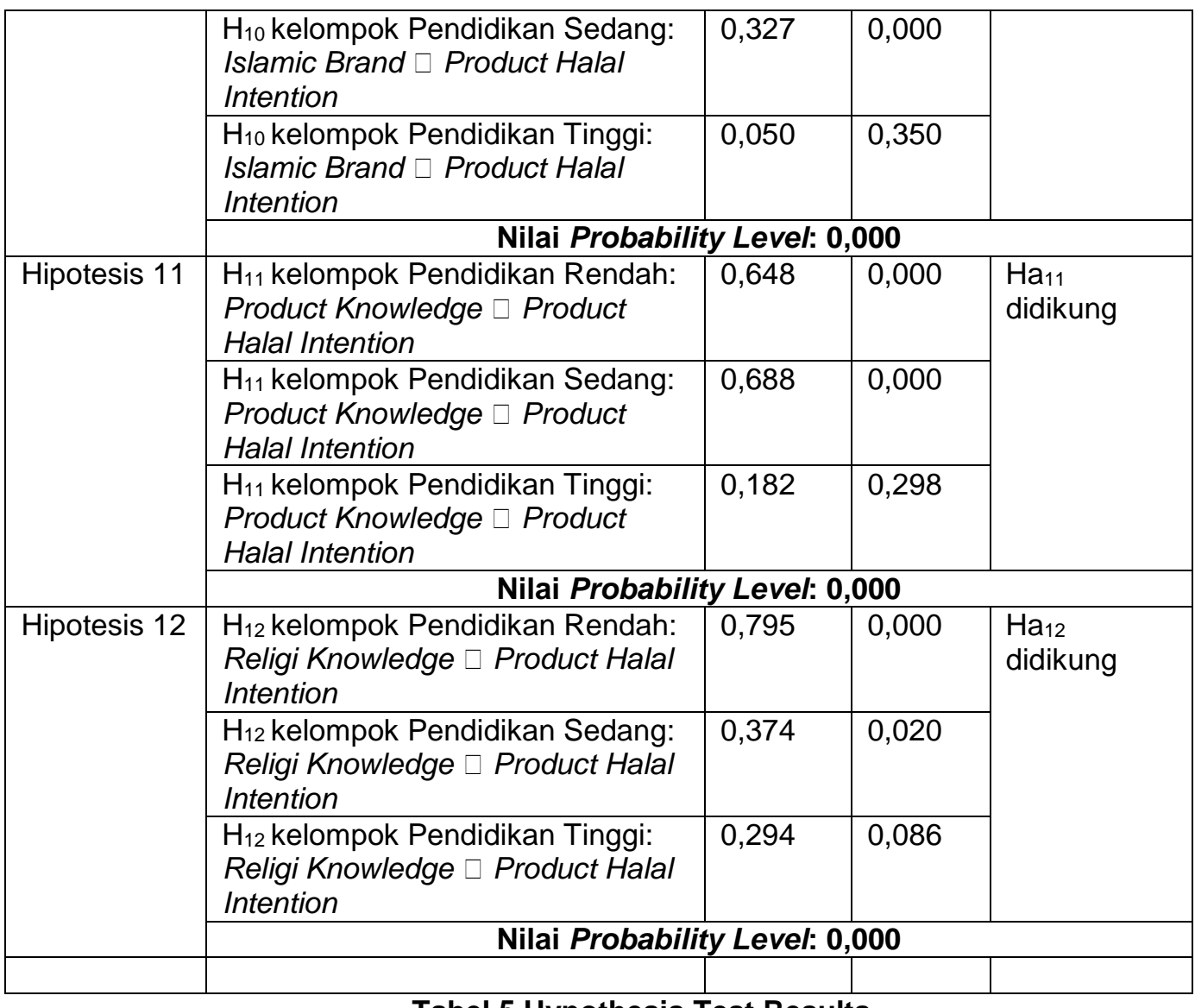

Tabel 5.Hypothesis Test Results

\section{Result and Discussion}

Research Result Analysis

The analysis of the results of this study was based on 225 respondents, and after mapping through profiles and descriptive analysis, the next step was testing the quality of the data. This test is essential because the data obtained from the survey with the questionnaire distribution must be able to be used in the research model or not.

\section{Price Variable}

Five indicators measure this price variable: affordable, according to shape, size, taste, packaging, and discounted prices.

(after removing the invalid P5 indicator)

\begin{tabular}{|c|c|c|c|}
\hline No. & \multicolumn{1}{|c|}{ Indikator } & Factor Loading & Keputusan \\
\hline $\mathbf{1 .}$ & $\begin{array}{l}\text { Menurut saya harga makanan dan } \\
\text { minuman halal sudah terjangkau. }\end{array}$ & 0,767 & Valid \\
\hline $\mathbf{2 .}$ & $\begin{array}{l}\text { Menurut saya harga makanan } \\
\text { dan minuman halal sudah } \\
\text { sesuai dengan rasa. }\end{array}$ & 0,835 & Valid \\
\hline $\mathbf{3 .}$ & $\begin{array}{l}\text { Menurut saya harga makanan dan } \\
\text { minuman halal sudah sesuai } \\
\text { dengan bentuk dan ukuran. }\end{array}$ & 0,862 & Valid \\
\hline $\mathbf{4 .}$ & $\begin{array}{l}\text { Menurut saya harga makanan dan } \\
\text { minuman halal sudah sesuai } \\
\text { dengan kemasan. }\end{array}$ & 0,785 & \\
\hline
\end{tabular}




\section{Tabel 6. Price Variable Validity Test Results}

The variable price validation test results show that only four indicators have factor loadings $>0.40$. On the other hand, there is one invalid indicator, P5, so the entry of the invalid statement must be discarded for all data to be valid. In addition, since the validity test was performed twice, one invalid index was removed, and then the variable price validity test was performed to confirm that all indexes had a factor loading value $>0.40$. Therefore, all items in the statement are considered valid when measuring price variables (Table 6).

\section{Problem}

Based on the background of opinions, research, and facts that occurred as described previously, thus the formulation of the problem in this research can be formulated, among others:

1. The demand for halal products is increasing, the market share is getting more expansive, and people's lifestyles are getting better. Only 29 percent of consumers in Indonesia pay attention to the halal label. At the same time, 59 percent prioritize taste and nutrition. The rest pay attention to the brand. Currently, the Indonesian Islamic community in consuming food products pays more attention to the expiration date than the halal label or the content of the product, and this is a finding from research from BPOM 2012.

2. The conditions and beliefs of the Indonesian Islamic community are still unfamiliar with halal certificated products. Most of the Muslim community believes that all products in Indonesia are halal in consuming various kinds of products on the market. Moreover, socialization about halal-labeled products to the public is still very lacking. This means that only some people are aware of the importance of the halal label on the halal product, who will find out the halal status of the product they consume.

Based on the background, problem formulation, and research objectives that have been described previously, the benefits of this research are:

1. For SMEs or business entities This research is expected to obtain helpful information for business entities or MSMEs in Indonesia how the behavior of consumers in meeting their food needs so that it can be a reference and take strategic steps in the development of halal products produced or distributed to the public.

2. For the world of academia

This research can provide scientific insight in making a curriculum related to consumer behavior better.

3. For the government The results of this study are expected to be a reference for the government in taking a policy related to meeting consumer needs for halal products. 


\section{Conclusion}

The study "Preference of Muslim Consumers Interested in Purchasing Halal Foods and Beverages at DKI Jakarta" reveals two variables: price, price unaffected, and significant due to other factors that have a greater impact on halal. Product concept. In addition, consumers do not have a problem with the current price, so the price does not affect consumers' purchasing decisions for halal products, and the Islamic brand in Jakarta does not cause much concern, or the hypothesis about the Islamic brand is not tested. While the level of consumer confidence in Jakarta is still absent and the meaning of the word "trust" in Islamic brands is not very strong, two other variables influence product knowledge and religious knowledge, and the hypothesis has been confirmed. Suppressing the gender variable while suppressing the influence of four independent variables (price, Islamic brand, product knowledge, and religious knowledge) on halal product intention supports the hypothesis. The disincentive effect of gender is the intentional price of halal products, and when it is divided into men and women, the effect of price on the intention of halal products is significantly reduced for men compared to women. The influence of Islamic brands on the intention of halal products with limited gender variables for both women and men supports the relationship or influence of the two variables. The influence of product knowledge on halal product intent can be mitigated by gender, where women dominate the influence of Islamic brands on halal product intent. The influence of religious knowledge on halal product intentions can be moderated by gender, where men dominate the influence of religious knowledge on halal product intentions.

The influence of independent variables (price, Islamic brand, product knowledge, and religious knowledge) on halal product intention was moderated by education level, supporting the hypothesis. By itself, when we divide education into three groups: low, middle, and high, the effect of price on the intention of halal products is that secondary education has a more powerful or dominant effect compared to lower education and higher education. Average and low education levels also mitigate the impact of Islamic brands on the intentions of halal products. Based on the research findings that meet the assigned tasks and objectives of the research, then some conclusions are drawn:

1. Price does not affect halal product intention. These results state that other factors directly have more influence on halal product intention. Consumers have no problem with the current prices to decide to purchase halal products. This is by HR Abu Dawud "from Anas Bin Malik. He said: People said, "O Messenger of Allah, the price has gone up, so fix the price for us." Then Rasulullah SAW said, verily Allah sets the price, narrows it down, and which expands, and I hope to meet Allah while one of you does not sue me for injustice in blood or wealth."

2. Islamic brand does not affect halal product intention. The results indicate that people in Jakarta are not very attentive, or the level of consumer confidence about Islamic brands is not so strong (Alserhan 2010).

3. Product Knowledge has an effect and is significant on halal product intention. The results of this study are by (Abdalla Mohamed Bashir 2019), (Vristiyana. 2019) (Ahmed et al. 2018), (Larasati, A., Hati, SRH, \& Safira 2018), (Rochmanto and Widiyanto 2015), (Aziz and Chok 2013), (FATLAHAH 2013), (Putranto and Kartoni 2020), (Kusuma 2014), (Lapian and Mandagie 2018) that product knowledge has a positive and significant effect on the purchase intention of a product.

4. Religion Knowledge has an effect and is significant on halal product intention. The results of this study are by research conducted by (Vristiyana. 2019), (Muhamad, Leong, and Mizerski 2015), (Wulandari 2021), (Astogini, Wahyudin, and Wulandari 2011), (Imamuddin, Syahrul, and Dantes 2020), (Larasati, A., Hati, SRH, \& Safira 2018), (Muhamad, Leong, and Mizerski 2015) which states that religious knowledge has a significant and significant effect on product purchase intentions.

5. Price has an effect on halal product intention with a moderating variable of gender. The male gender who moderates the price of halal products in intention is stronger than the female gender, and this indicates that women do not pay much attention to the price level of food and beverage products, as long as the food is sufficient to satisfy consumption. 
6. Islamic brand affects halal product intention with gender moderating variable. The gender moderating variable further strengthens the relationship between Islamic brands and product intention, where both male and female gender has an equally strong influence.

7. Product Knowledge affects product halal intention with a moderating variable of gender. Gender groups of women and men have substantial power in moderating the relationship between product knowledge and product halal intention.

8. Religious knowledge affects halal product intention with a moderating variable of gender. The groups of women and men both strengthen the relationship between religious knowledge and product intention.

9. Price affects product halal intention with the moderating variable of education level. The moderating variable for education level consists of three groups, so only the moderate education group can strengthen the relationship between price and product intention.

10. Islamic brand affects halal product intention with a moderating variable of education level. Low and moderate education levels can moderate or strengthen the relationship of Islamic brands to halal product intention.

11. Product Knowledge affects product halal intention with a moderating variable for education level. Moderate variables for moderate and low levels of education strengthen the relationship between product knowledge and product halal intention.

12. Knowledge religion affects halal product intention with a moderating variable at the level of education. The level of education is low and is strengthening the relationship between religious knowledge and product intention.

\section{References}

[1] L. Adriani and Ma'ruf, "Pengaruh Islamic Religiosity dan Halal Knowledge terhadap Purchase Intention Kosmetik Halal Dimediasi oleh Attitude terhadap Produk Halal di Indonesia," Al-Muzara'Ah, vol. 8, no. 1, pp. 57-72, 2020, doi: 10.29244/jam.8.1.57-72.

[2] A. Ali, A. Ali, Z. Ali, and M. Sherwani, "Investigating the antecedents of halal brand product purchase intention : an empirical investigation," J. Islam. Mark. O Emerald Publ. Ltd., 2020, doi: 10.1108/JIMA-03-2019-0063.

[3] A. M. Bashir, "Effect of halal awareness, halal logo and attitude on foreign consumers ' purchase intention," 2019, doi: 10.1108/BFJ-01-2019-0011.

[4] Y. Edy Yulianto Putra1*, "ANALISIS FAKTOR-FAKTOR YANG MEMPENGARUHI NIAT BELI KONSUMEN PRODUK MAKANAN DAN MINUMAN 'HALAL' DI KOTA BATAM," vol. 2 Number 2, pp. 73-88, 2020.

[5] M. Imamuddin, S. Syahrul, and R. Dantes, "Pengaruh Label Halal Dimoderasi Religiusitas Terhadap Keputusan Pembelian Produk Kemasan Oleh Mahasiswa PTKIN Se-Sumatera Barat," KABILAH J. Soc. Community, vol. 5, no. 1, pp. 14-25, 2020, doi: 10.35127/kbl.v5i1.3884.

[6] S. Khadijah1 and O. A. Wulandari2, "ISLAMIC BRANDING RESTORAN KOREA TERHADAP MINAT BELI KONSUMEN," vol. 6, No. 1Ma, no. 1, pp. 16-29, 2020.

[7] D. S. S. Wuisan, "Pengaruh e-service quality dan food quality terhadap customer loyalty pengguna GoFood Indonesia yang dimediasi oleh perceived value dan customer satisfaction," JMBI UNSRAT (Jurnal IIm. Manaj. Bisnis dan Inov. Univ. Sam Ratulangi)., vol. 8, no. 1, 2021.

[8] G. P. Mulasakti and F. Mas'ud, "Faktor Penentu Minat Beli Produk Makanan dan Minuman Impor Berlabel Halal," J. IIm. Ekon. Islam, vol. 6, no. 2, pp. 294-303, 2020.

[9] I. Putranto and K. Kartoni, "Pengaruh Kualitas Produk dan Harga Terhadap Keputusan Pembelian Tupperware (Studi Kasus Ibu Rumah Tangga di Perumahan Kunciran Tangerang)," J. Mandiri IImu Pengetahuan, Seni, dan Teknol., vol. 4, no. 1, pp. 94-104, 2020, doi: 10.33753/mandiri.v4i1.107.

[10] S. Wulandari, "Pengaruh Label Halal Dan Religiusitas Terhadap Keputusan Pembelian (Studi Kasus Konsumen Indomie Di Sidoarjo)," J. Ris. Manaj. dan Bisnis Dewantara, vol. 4, no. 1, pp. 31-36, 2021.

[11] A. K. Badri, J. Heikal, Y. A. Terah, and D. R. Nurjaman, "Decision-Making Techniques using LSTM on Antam Mining Shares before and during the COVID-19 Pandemic in Indonesia," APTISI Trans. Manag., vol. 6, no. 2, pp. 167-180, 2022.

[12] A. R. S. Panjaitan, U. Rahardja, Q. Aini, N. P. L. Santoso, and D. Apriliasari, "The 
Management Innovation of Kuliah Kerja Praktek (KKP)," APTISI Trans. Manag., vol. 6, no. 1, pp. 62-73, 2022.

[13] W. Setyowati and A. Sofingi, "Determinants of Employee Performance with Work Motivation as an Intervening Variable at the Semarang City Search and Rescue Office," APTISI Trans. Manag., vol. 6, no. 1, pp. 19-29, 2022.

[14] N. Lutfiani, U. Rahardja, and K. T. Khasanah, "The Development Viewboard As an Information Media at Official Site Asosiation," APTISI Trans. Manag., vol. 6, no. 1, pp. 1018, 2022.

[15] Q. Aini, N. Lutfiani, N. P. L. Santoso, S. Sulistiawati, and E. Astriyani, "Blockchain For Education Purpose: Essential Topology," Aptisi Trans. Manag., vol. 5, no. 2, pp. 112-120, 2021.

[16] J. Heikal, V. Rialialie, D. Rivelino, and I. A. Supriyono, "Hybrid Model Of Structural Equation Modeling Pls And Rfm (Recency, Frequency And Monetary) Model To Improve Bank Average Balance," Aptisi Trans. Technopreneursh., vol. 4, no. 1, pp. 1-8, 2022.

[17] H. Haryani, E. Astriyani, and V. T. Devana, "Exploration of Islamic Religious Learning Innovation Technology with the iLearning Approach," Aptisi Trans. Technopreneursh., vol. 3, no. 2, pp. 73-84, 2021.

[18] A. Kumar, P. Bhandari, and K. S. Rawat, "Numerical Simulation of Solar Air Heater using Paraffin Wax-Aluminum Compound as Phase Changing Material," Aptisi Trans. Technopreneursh., vol. 3, no. 2, pp. 49-55, 2021.

[19] N. Lutfiani, A. Khoirunisa, A. Faturahman, and E. A. Nabila, "RETRACTED (ditarik): Science Literacy in Early Childhood: Development of Learning Programs in the Classroom," Aptisi Trans. Technopreneursh., vol. 3, no. 2, pp. 30-36, 2021.

[20] B. P. Singh, V. S. Bisht, P. Bhandari, and K. S. Rawat, "Thermo-Fluidic Modelling of a Heat Exchanger Tube with Conical Shaped Insert having Protrusion and Dimple Roughness," Aptisi Trans. Technopreneursh., vol. 3, no. 2, pp. 13-29, 2021. 